\title{
片肺換気において麻酔薬が $\mathrm{PaO}_{2}$ に与える影響 —プロポフォールとイソフルランの比較—
}

\author{
小村好弘*1 加藤 学*1 森本佳子*1
}

森本裕二*2 劍物 修*2

\begin{abstract}
要旨 片肺換気を必要とする麻酔時に, 術中低酸素状態をきたすことがある．近年，プロポフォー ルは低酸素性肺血管収縮を抑制しないため, 片肺換気において吸入麻酔薬より有利であるという報 告がある，今回われわれは, 術中片肺換気を必要とする手術 32 例をプロポフォール維持群 $(\mathrm{P}$ 群) 16例, 吸入麻酔群(I群) 16例に分け, $\mathrm{PaO}_{2}$ がどのように変化するかを調べた. $100 \%$ 酸素で換気し, 側臥位両肺換気時, 片肺換気開始 15 分, 30 分, 60 分後, 及び 40 \%酸素で両肺換気 15 分後の動脈 血ガス分析を比較した．その結果, 片肺換気 15 分後における $\mathrm{PaO}_{2}$ 值は I 群 $197.9 \mathrm{mmHg}$ に対し, P 群 $281.7 \mathrm{mmHg}$ と有意に高かったそその原因はプロポフォールは吸入麻酔薬に比べて低酸素性肺血 管収縮の抑制が少ないためと考えられた。プロポフォールは片肺換気の麻酔維持に適した麻酔薬と 結論した。

キーワード：片肺換気，プロポフォール，低酸素性肺血管収縮
\end{abstract}

\section{I はじめに}

分離肺換気の適応が拡大され，術中片肺換気によ る麻酔管理の機会が増加している.さらに近年, プロ ポフォールの臨床導入により静脈麻酔薬による麻酔 管理が増加している. 片肺換気時の肺酸素化能に関 して, 吸入麻酔薬よりプロポフォールがよいとする 報告 ${ }^{1) \sim 3)}$, 差はないとする報告 ${ }^{4), 5)}$ 等, 麻酔管理にお ける相違が論じられている。臨床で問題となるのは, 片肺換気における低酸素血症である。低酸素性肺血 管収縮(hypoxic vasoconstriction：HPV)に対する抑 制の違いは，麻酔方法の違いによるものである。そ のことが, 低酸素血症の発現に大きく影響すると考え られる.今回われわれは, プロポフォールによる麻酔

*1 恵佑会札幌病院麻酔科

*2 北海道大学医学部侵襲制御医学教室

受理日 1999.4 .7
維持とイソフルランによる麻酔維持とにおいて, 片 肺換気中の動脈血ガス分析を経時的に行ない，麻酔 法の違いが片肺換気に与える影響を比較・検討した。

\section{II 対象と方法}

対象は当院で行なわれた食道癌手術, 肺癌手術で, 側臥位片肺換気を必要とする予定手術症例である. 麻酔維持の方法によりプロポフォール維持群(P群) と, イソフルランによる吸入麻酔群 (I群)の 2 群に分 けた。

麻酔導入は, 全例プロポフォール $2 \mathrm{mg} \cdot \mathrm{kg}^{-1}$, ベ クロニウム $1.2 \mathrm{mg} \cdot \mathrm{kg}^{-1}$ で行なつた. 二腔気管チュ ーブを挿管後, 麻酔導入より片肺換気終了まで 100 \%酸素で換気した. P群は, プロポフォールを ステップダウン法により $10 \mathrm{mg} \cdot \mathrm{kg}^{-1} \cdot \mathrm{h}^{-1}$ から開始 し, $6 \mathrm{mg} \cdot \mathrm{kg}^{-1} \cdot \mathrm{h}^{-1}$ 前後で維持した. I群では, イ ソフルランを適宜濃度を変えて維持した。術中は両 
表 1 患者背景 (1)

\begin{tabular}{r|r|r|r}
\hline & \multicolumn{1}{c|}{ P群 } & \multicolumn{1}{c|}{ I 群 } \\
\hline 身長 $(\mathrm{cm})$ & $163.2 \pm 2.08$ & $163.7 \pm 1.72$ & $\mathrm{~ns}$ \\
体重 $(\mathrm{kg})$ & $57.4 \pm 2.16$ & $56.6 \pm 2.34$ & $\mathrm{~ns}$ \\
\%VC(\%) & $94.9 \pm 5.81$ & $102.2 \pm 4.19$ & $\mathrm{~ns}$ \\
\%FEV1.0(\%) & $76.8 \pm 2.56$ & $77.6 \pm 2.34$ & $\mathrm{~ns}$ \\
& & & \\
手術時間(min) & $214.7 \pm 24.08$ & $295.1 \pm 30.56$ & $\mathrm{p}=0.047$ \\
\hline
\end{tabular}

表2 患者背景 (2)

\begin{tabular}{l|r|r}
\hline & P群 & \multicolumn{1}{|c}{ 群 } \\
\hline 原疾患 & & \\
食道癌 & 10 & 13 \\
肺癌 & 5 & 3 \\
縦隔腫瘍 & 1 & 0 \\
\hline 開胸側 & & \\
右 & 16 & 13 \\
左 & 0 & 3 \\
\hline
\end{tabular}

表中の数字は症例数

表3 術中動脈血ガス分析值, 収縮期血圧

\begin{tabular}{|c|c|c|c|c|c|c|}
\hline & & 両肺control & 片肺15min & 片肺30min & 片肺60min & 両肺 $40 \% 02$ \\
\hline \multirow[t]{2}{*}{$\mathrm{PaO}_{2}$} & P群 & $501.4 \pm 21.3$ & $281.7 \pm 28.2^{\star}$ & $226.4 \pm 27.3$ & $203.2 \pm 30.5$ & $176.9 \pm 11.0$ \\
\hline & I群 & $475.3 \pm 17.1$ & $197.9 \pm 21.1$ & $178.2 \pm 19.3$ & $189.4 \pm 24.8$ & $147.6 \pm 11.3$ \\
\hline \multirow[t]{2}{*}{$\mathrm{PaCO}_{2}$} & P群 & $40.1 \pm 1.13$ & $39.1 \pm 1.50$ & $37.8 \pm 1.38$ & $36.6 \pm 1.33^{*}$ & $37.9 \pm 1.48$ \\
\hline & １群 & $37.8 \pm 1.17$ & $38.9 \pm 1.44$ & $38.5 \pm 1.68$ & $41.7 \pm 1.74$ & $38.8 \pm 1.65$ \\
\hline \multirow[t]{2}{*}{$\mathrm{pH}$} & P群 & $7.385 \pm 0.008$ & $7.397 \pm 0.011$ & $7.403 \pm 0.012$ & $7.413 \pm 0.013^{\star}$ & $7.397 \pm 0.011$ \\
\hline & １群 & $7.396 \pm 0.014$ & $7.389 \pm 0.015$ & $7.388 \pm 0.016$ & $7.365 \pm 0.018$ & $7.375 \pm 0.015$ \\
\hline \multirow[t]{2}{*}{ 収摍期血压 } & P群 & $96.6 \pm 3.67$ & $111.9 \pm 3.99$ & $103.4 \pm 2.52$ & $105.3 \pm 4.85$ & $101.2 \pm 2.71$ \\
\hline & I群 & $109.7 \pm 5.51$ & $104.4 \pm 5.66$ & $103.9 \pm 3.27$ & $115.4 \pm 4.36$ & $105.9 \pm 5.36$ \\
\hline
\end{tabular}

* $p<0.05$ ( ( 群に対し)

群とも硬膜外麻酔とフェンタニルを適宜使用した。 硬膜外麻酔は第 $7 / 8$ 胸椎間より挿入し，20万倍エピ ネフリン添加 $1.5 \%$ リドカインを用いた。換気量は 分時換気量 $100 \mathrm{~m} l \cdot \mathrm{kg}^{-1} \cdot \mathrm{min}^{-1}$ を目安に設定し，片 肺換気時にはその分時換気量が維持できるように 1 回換気量と換気回数を設定した. 測定項目は, $\mathrm{PaO}_{2}$, $\mathrm{PaCO}_{2}, \mathrm{pH}$ ，収縮期血圧とした，測定間隔は，側臥 位両肺換気時, 片肺換気開始 15 分, 30 分, 60 分後, 両肺換気に戻し $40 \%$ 酸素に調整して 15 分後とした。 結果は平均值士標準誤差で表し, 統計学的処理は患 者背景は $t$-検定を, 群間の比較には repeated measures ANOVAを用い, $\mathrm{p}<0.05$ を有意差ありとした.

\section{III 結 果}

対象患者は, 年齢50〜 77歳の 32 症例であった. 男 女比は男性 28 例, 女性 4 例で, P群 16 症例, I群 16 症
例に振り分けた.両群間に, 身長, 体重, 呼吸機能等に 有意差はなかった. 手術時間はI群で $295.0 \pm 30.6$ 分 と, P 群の $214.7 \pm 24.1$ 分より有意に長かった(表 1 ). 原疾患, 開胸側は表 2 に示すとおりである。P群に おいて, 食道癌 10 例, 肺癌 5 例, 縦隔腫瘍 1 例で 16 例すべて右開胸であったＩI群では食道癌 13 例, 肺 癌 3 例で，右開胸 13 例，左開胸 3 例であった。測定 結果を表 3 に示す. $\mathrm{PaO}_{2}$ は, 片肺換気開始 15 分後に おいて P 群が $281.7 \pm 28.2 \mathrm{mmHg}$ で，I群の $197.9 \pm$ $21.1 \mathrm{mmHg}$ に比べ有意に高かった。 $\mathrm{PaCO}_{2}$ は，片肺 換気開始 60 分後においてI群が $41.7 \pm 1.7 \mathrm{mmHg}$ で, $\mathrm{P}$ 群の $36.6 \pm 1.3 \mathrm{mmHg}$ より有意に高かった。それに 伴い $\mathrm{pH}$ は，片肺換気開始 60 分後においてI群が $7.365 \pm 0.018$ で $\mathrm{P}$ 群の $7.413 \pm 0.013$ より有意に低下 した。その他は両群間において有意差はなかった。 


\section{I 考察}

術中片肺換気により術中低酸素血症を起こす原因 は, 生理学的死腔の増大, 肺内シャントの増加, 拡 散障害, 換気血流比の不均等などが考えられる ${ }^{6)}$.そ の中でも, 特にHPVの関与が大きいとされている77. 吸入麻酔薬と静脈麻酔薬とでは, HPVに対する影響 が異なると報告されている ${ }^{8)}$.八ロタン, エンフルラ ン, イソフルランは濃度依存性に HPV を抑制すると いう報告が多くみられる．動物実験においてもさま ざまな報告があり, 臨床使用量ではシャント率は増 加するが, $\mathrm{PaO}_{2}$ には影響しなかったとする報告が多 (1),2,4),5).これに対しプロポフォールは, シャント率 を増加させないという利点があり, 用量を増やしても シャント率に対して変化が見られず9)，また $\mathrm{PaO}_{2}$ に も影響を与えないとする報告がみられる ${ }^{1) \sim 31,5), 91,10) . ~}$ 今回の研究において，片肺換気開始 15 分後における $\mathrm{PaO}_{2}$ の值が $\mathrm{P}$ 群で有意に高かった。この事実は，プ ロポフォールと吸入麻酔薬の HPVに対する抑制度 の差がシャント率の違いを生じ, $\mathrm{PaO}_{2}$ の差として現 われたと考えられる。

HPVに影響を与える因子として麻酔薬の他にも いくつか考えられる。心係数の減少はHPVを増強 する. 吸入麻酔薬やプロポフォール等も, 心拍出量 を低下させるために HPVを増強するが, 薬剤そのも のの HPV 抑制と相反するため, 臨床上 $\mathrm{PaO}_{2}$ の值が さまざまな結果になるものと考えられる。さらに $100 \%$ 酸素を吸入することで，末梢気道が閉塞する ように㗢くため $\dot{\mathrm{V}} / \dot{\mathrm{Q}}$ の不均衡が生じ, $\mathrm{PaO}_{2}$ が低下 することがある。また，硬膜外麻酔は HPV を増強 するという報告もある ${ }^{11)}$.これらがお互いに影響し 合い, 臨床上さまざまな肺酸素化能の結果が現れる ものと考えられる。しかし今回の研究では，硬膜外 麻酔は同じように併用しており, 吸入気酸素濃度も $100 \% て ゙$ 統一しているため, これらの影響による差 は少ないと思われる. 心拍出量は, イソフルランに 比較して，プロポフォールの方が低下する ${ }^{5)}$ という 報告がある，そのためにプロポフォールの方が HPV
をより増強させ, 片肺換気開始 15 分後の肺酸素化能 に差が出たと考えることもできる. しかし今回の研 究ではどのように影響したかは不明である。

$\mathrm{PaCO}_{2}$ に関しては, I群の片肺換気開始 60 分後の $\mathrm{PaCO}_{2}$ が P 群に比べ高值であった。片肺換気により 流入するガス量が減少すると, 肺胞内では酸素の吸 収によるガス体積の減少が $\mathrm{CO}_{2}$ 排泄によるガス体積 の増加より大きいため $\mathrm{PACO}_{2}$ を上昇させる。 それに 伴い肺胞が虚脱する方向へ動く，その結果，この肺 胞が虚脱する前にそこを通る血流があると血中 $\mathrm{CO}_{2}$ が上昇する，吸気中の酸素濃度が高いほど，あるい は心拍出量が減少し $\mathrm{PVO}_{2}$ が低下するほど肺胞中の $\mathrm{CO}_{2}$ の血中への取り込みが増すので, この現象は起 こりやすくなる。吸入麻酔薬の方がプロポフォール より HPVの抑制が強いため, 非換気側肺における これらの虚脱する前の肺胞への血流が維持され, $\mathrm{PACO}_{2}$ 濃度が上昇し，ひいては $\mathrm{PaCO}_{2}$ の上昇に影響 したと考えられる。それに伴い $\mathrm{pH}$ の変化も現れた と推測できる.しかし，この $\mathrm{PaCO}_{2}$ の上昇の原因が これだけとは考えづらく，麻酔深度の変化による $\mathrm{CO}_{2}$ 産生量の変化ともあわせて, 今後も検討する必 要があるものと思われる.

以上のように, プロポフォールは片肺換気時の麻 酔維持において吸入麻酔薬に比べて, 片肺換気初期 の動脈血酸素濃度を高く維持することができた。プ ロポフォールは, 吸入麻酔薬に比べて片肺換気を伴 う麻酔維持において有利な麻酔薬と考えられる。

この論文の要旨は, 第 18 回日本臨床麻酔学会総 会(1998, 松山)において発表した.

\section{参考文献}

1) Abe K, Shimizu T, Takashima M, et al. : The effects of propofol, isoflurane, and sevoflurane on oxygen and shunt fraction during one-lung ventilation. Anesth Analg $87: 1164 \sim 1169,1998$

2) Martin E, Spies C, Zaune U : A comparison of three anaesthetic regimens for pulmonary surgery. Focus on Infusion : $145 \sim 146,1991$ 
3）古竪智佐子, 佐藤圭路, 小坂義弘：プロポフォール麻 酔下片肺換気中における肺胞気一動脈血酸素分圧較差 $\left(\mathrm{A}-\mathrm{aDO}_{2}\right)$. 麻酔と蘇生 $33: 21 \sim 23,1997$

4) Reid CW, Slinger PD, Lenis S : A comparison of the effects of propofol-alfentanil versus isoflurane anesthesia on Arterial oxygenation during one-lung ventilation. J Cardiothorac Vasc Anesth $10: 860 \sim 863,1996$

5) Kellow NH, Scott AD, White SA, et al. : Comparison of the effects of propofol and isoflurane anaesthesia on right ventricular function and shunt fraction during thoracic surgery. Br J Anaesth $75: 578 \sim 582,1995$

6）侘美好昭：麻酔による肺換気の変化, 最新麻酔科学. 稲田豊編. 克誠堂出版, 東京, 1989, 724 737

7）石部裕一, 山㠃和雄, 上田敬一郎ほか：片肺換気と低 酸素性肺血管収縮. 日臨麻会誌 $18 ： 561 ５ 69,1998$

8）行岡秀和：肺循環と麻酔. 臨床麻酔 $17 ： 1025 \sim 1032$, 1993
9) Boldt J, Muller M, Uphus D, et al. : Cardiorespiratory changes in patients undergoing pulmonary resection using different anesthetic management techniques. J Cardiothorac Vasc Anesth 10:854 859, 1996

10) Steegers PA, Backx PJ : Propofol and alfentanil anesthesia during one-lung ventilation. J Cardiothorac Anesth $4: 194 \sim 199,1990$

11) Ishibe $Y$, Shiokawa $Y$, Ueda $T$, et al. : The effect of thoracic epidural anesthesia on hypoxic pulmonary vasoconstriction in dogs : an analysis of the pressure flow curve. Anesth Analg $82: 1049 \sim 1055,1996$

\author{
著者連絡先 小村好弘 \\ 干 003-0027 札幌市白石区本通 14丁目北 1-1 \\ 恵佑会札幌病院麻酔科
}

\title{
The Effects of Anesthetic Management on Arterial Oxygenation during One-lung Ventilation - Comparison between Propofol and Isoflurance -
}

\author{
Yoshihiro KOMURA*, Manabu KATO*, Yoshiko MORIMOTO*, \\ Yuji MORIMOTO**, Osamu KEMMOTSU** \\ * Department of Anesthesia, Keiyukai Sapporo Hospital \\ ** Department of Anesthesiology, Hokkaido University School of Medicine
}

There are several cases of hypoxemia during one-lung ventilation. Anesthetic agents are reported to reduce hypoxic response of the lung. The aim of this study was to evaluate the effect of isoflurane and propofol on oxygenation during one lung ventilation (OLV). We studied 26 patients who had OLV procedure for elective thoracic surgery, lung cancer and esophageal cancer. In 13 patients (I group) were anesthetized with isoflurane. Another 13 patients (P group) were anesthetized with propofol. The patients in both groups received thoracic epidural anesthesia with lidocaine beside general anesthesia. A double-lumen endotrachial tube was inserted, and mechanical ventilation with $100 \%$ oxygen was performed. Arterial blood gases were recorded in a lateral position with two-lung ventilation, $15 \mathrm{~min}, 30 \mathrm{~min}, 60 \mathrm{~min}$ after one lung ventilation. The mean value for $\mathrm{PaO}_{2}$ during OLV in $\mathrm{P}$ group after $15 \mathrm{~min}(281.7 \pm 28.2 \mathrm{mmHg})$ were significantly $(\mathrm{p}<0.05)$ higher than that in I group $(197.9 \pm 21.1 \mathrm{mmHg})$. This findings suggest that propofol is suitable for one-lung ventilation than isoflurane.

Key Words : One-lung ventilation, Propofol, Hypoxic vasoconstriction 